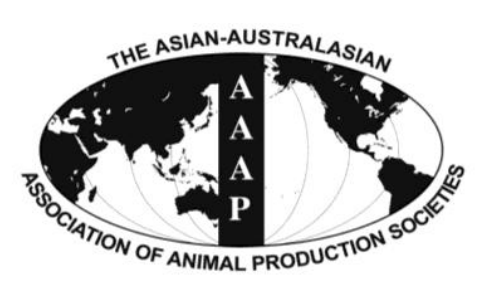

Open Access

Asian Australas. J. Anim. Sci.

Vol. 28, No. 6 : 788-795 June 2015

http://dx.doi.org/10.5713/ajas.14.0790

www.ajas.info

pISSN $1011-2367$ elSSN 1976-5517

\title{
Proteomic Analysis of Bovine Pregnancy-specific Serum Proteins by 2D Fluorescence Difference Gel Electrophoresis
}

\author{
Jae Eun Lee, Jae Young Lee, Hong Rye Kim, Hyun Young Shin, Tao Lin, and Dong Il Jin* \\ Department of Animal Science, Chungnam National University, Daejeon 305-764, Korea
}

\begin{abstract}
Two dimensional-fluorescence difference gel electrophoresis (2D DIGE) is an emerging technique for comparative proteomics, which improves the reproducibility and reliability of differential protein expression analysis between samples. The purpose of this study was to investigate bovine pregnancy-specific proteins in the proteome between bovine pregnant and non-pregnant serum using DIGE technique. Serums of 2 pregnant Holstein dairy cattle at day 21 after artificial insemination and those of 2 non-pregnant were used in this study. The pre-electrophoretic labeling of pregnant and non-pregnant serum proteins were mixed with Cy3 and Cy5 fluorescent dyes, respectively, and an internal standard was labeled with Cy2. Labeled proteins with Cy2, Cy3, and Cy5 were separated together in a single gel, and then were detected by fluorescence image analyzer. The 2D DIGE method using fluorescence CyDye DIGE flour had higher sensitivity than conventional 2D gel electrophoresis, and showed reproducible results. Approximately 1,500 protein spots were detected by 2D DIGE. Several proteins showed a more than 1.5-fold up and down regulation between non-pregnant and pregnant serum proteins. The differentially expressed proteins were identified by MALDI-TOF mass spectrometer. A total 16 protein spots were detected to regulate differentially in the pregnant serum, among which 7 spots were up-regulated proteins such as conglutinin precursor, modified bovine fibrinogen and IgG1, and 6 spots were down-regulated proteins such as hemoglobin, complement component 3 , bovine fibrinogen and IgG2a three spots were not identified. The identified proteins demonstrate that early pregnant bovine serum may have several pregnancy-specific proteins, and these could be a valuable information for the development of pregnancy-diagnostic markers in early pregnancy bovine serum. (Key Words: 2D DIGE, CyDye, Proteomics, Bovine Pregnancy, Pregnancy-specific Serum Proteins)
\end{abstract}

\section{INTRODUCTION}

The bovine pregnancy was detected routinely by palpation per rectum at 60 days after at artificial insemination (AI) or ultrasonography at 35 days after AI (Oltenacu et al., 1990; Nation et al., 2003). Progesterone concentration in milk has also become a method for detection of bovine pregnancy (Pyo et al., 2003). The early pregnant cows have numerous signals such as steroids, prostaglandins, and many protein factors (Bartol et al., 1985; Knickerboker et al., 1986). These proteins produced by uterus and placenta have been used to detect pregnancy for many years in other species (Yuan et al., 2006). More

* Corresponding Author: Dong Il Jin. Tel: +82-42-821-5876, Fax: +82-42-822-6712, E-mail: dijin@cnu.ac.kr

Submitted Oct. 11, 2014; Revised Dec. 15, 2014; Accepted Jan. 19, 2015 recently, pregnancy-specific protein $\mathrm{B}$, which is a placental glycoprotein (Butler et al., 1982; Sasser et al., 1989) has been measured by radio-immnunoassay method (Sasser et al., 1986; Perenyi et al., 2002) in serum of pregnant cow. For development of any marker proteins from complex biological fluids, such as plasma, serum and urine, twodimensional (2D) gel electrophoresis technique is routinely used in many laboratories (Bichsel et al., 2001; Zhou et al., 2002; Morita et al., 2006). In addition, Bovine samples have been reported by several previous studies of high-resolution 2D gel electrophoresis (Talamo et al., 2003; Berendt et al., 2005). Hochstrasser et al. (1997) had used 2 dimensional SDS-polyacrylamide gel electrophoresis (2D SDS-PAGE) technique to identify potential bovine serum encephalitisspecific markers on bovine colony stimulating factor samples. And Manabe et al. (1987) had performed a native 2D electrophoresis for mapping adult and fetal bovine

Copyright $@ 2015$ by Asian-Australasian Journal of Animal Sciences This is an open-access article distributed under the terms of the Creative Commons Attribution Non-Commercial License (http://creativecommons.org/licenses/by-nc/3.0/), which permits unrestricted non-commercial use, distribution, and reproduction in any medium, provided the original work is properly cited. 
plasma and serum.

The 2D gel electrophoresis technique is well known and commonly used for proteomic separation. But it requires time-consuming and labor-intensive as well as low reproducibility between gels due to comparison analysis using many gels. Thus it could be difficult to distinguish the difference among gels and induce lots of variation (Yan et al., 2002; Chromy et al., 2004; Marouga et al., 2005). Moreover, the protein visualization methods such as Coomassie brilliant blue (CBB) or silver staining are inherently variable. To improve the limitation of 2D gel method like a low reproducibility and gel to gel variation, 2D fluorescence difference gel electrophoresis (DIGE) were introduced with co-detection of up to three samples on the same single 2D gel, which could minimize the gel-to-gel variation (Raggiaschi et al., 2006).

The 2D DIGE technique was first described by Unlu group in 1997 to introduce a feature to separate more than one sample in a single $2 \mathrm{D}$ polyacrylamide gel. This technique involved pre-labeling two protein extracts, using two fluorescent cyanine dyes known as $\mathrm{Cy} 3$ and $\mathrm{Cy} 5$. The labeled samples were then mixed and run on the same 2D gel. Amersham Biosciences (now part of GE Healthcare) had acquired exclusive license for this technology from Carnegie Mellon University, and published firstly the study of N-acetyl-p-aminophenol toxicity in mouse liver (Anderson et al., 2001; Tong et al., 2001). More recently, Amersham Biosciences has also introduced third fluorescent dye, known as $\mathrm{Cy} 2$, making it possible to compare three samples on one 2D gel. The Cy2 fluorescence dye has similar properties with $\mathrm{Cy} 3$ and $\mathrm{Cy} 5$. The protein samples are then visualized by using fluorescence imaging to enable detection of differences between protein abundance in the three samples. The samples expressed by coloring in three kinds of fluorescence from protein abundance can be separated in the single gel. Three different color images can be acquired from the same gel after background subtraction and normalization. The ability to directly compare three samples on the same gel not only avoids the complications of gel-togel variation but also enables a more accurate and rapid analysis of differences and reduces the number of gels that need to be run. It also utilizes DeCyder (Differential Analysis Software, GE Healthcare Bio-Sciences, Uppsala, Sweden), newly developed image analysis software for DIGE for removing user subjectivity and increasing automation of the analysis.

In this study, we carried out the fluorescence 2D DIGE technique on bovine serums to identify the pregnantspecific serum proteins between pregnant and non-pregnant bovine serums, because 2D DIGE is more sensitive and reproducible than conventional $2 \mathrm{D}$ gel electrophoresis technique (Gharbi et al., 2001; Marouga et al., 2005).

\section{MATERIALS AND METHODS}

\section{Serum sample preparation}

Bovine serum sample: We prepared serums of 2 pregnant Holstein cattle at day 21 after AI and those of 2 non-pregnant cattlte for analyzing of proteomics. The samples were collected in Animal Research Center of Chungnam National University. After the fresh bovine blood was collected in a heparinized tube and centrifuged at $1,000 \times \mathrm{g}$ at $4^{\circ} \mathrm{C}$ for 10 minute, the supernatant serum was collected and stored at $-20^{\circ} \mathrm{C}$ until use.

Extraction of serum soluble proteins: Lysis buffer containing $0.3 \%$ SDS, 3\% dithiothreitol (DTT), protease inhibitor cocktail (complete; Roche Diagnostic GmbH Inc., Mannheim, Germany), 0.5 M Tris/ $\mathrm{HCl}$ ( $\mathrm{pH} 8.5$ ) was used for equal volume to serum (100 $\mu \mathrm{L}$ buffer $/ 100 \mu \mathrm{L}$ serum), and samples were sonicated for 15 seconds and then chilled on ice. The samples were shaken gently for $1 \mathrm{~h}$ at room temperature. Insoluble material was removed by centrifugation at $15,000 \times \mathrm{g}$ at $4{ }^{\circ} \mathrm{C}$ for $10 \mathrm{~min}$. The concentration of soluble protein was determined by the $2 \mathrm{D}$ Quant kit (GE Healthcare Bio-Sciences, Sweden) and then final protein samples were stored in aliquot at $-70^{\circ} \mathrm{C}$ until use.

\section{Labeling of fluorescence CyDye}

Preparation of CyDye DIGE flour stock solution: CyDye DIGE flour, minimal labeling kit, $5 \mathrm{nmol}$ (Cy2, Cy3, Cy5, GE Healthcare Bio-Sciences, Sweden) was left alone 5 minutes at normal temperature in light cutoff by putting out at $-20^{\circ} \mathrm{C}$. The $5 \mu \mathrm{L}$ dimethylformamide (DMF) was added to each flour tube to be with a concentration $1 \mathrm{nmol} / \mu \mathrm{L}$ of flours. The samples were mixed by vortex about 30 seconds and span down, and stored by wrapping with foil for light cutoff at $-20^{\circ} \mathrm{C}$ before using.

Preparation of CyDye DIGE flour working solution: After spinning down stock flour solution, working solution of 400pmol was made for labeling $50 \mu \mathrm{g}$ of serum protein. Working solution $(5 \mu \mathrm{L})$ was made by adding $3 \mu \mathrm{L}$ DMF and $2 \mu \mathrm{L}$ stock flour solution.

CyDye labeling and experiment design: For CyDye labeling, $1 \mu \mathrm{L}$ of $\mathrm{Cy} 5$ working solution $(400 \mathrm{pmol})$ and 1 $\mu \mathrm{L}$ of $\mathrm{Cy} 3$ working solution (400 pmol) were added to two samples of bovine non-pregnant and pregnant bovine serums $(50 \mu \mathrm{g})$, and then mixed by vortex. To make internal standard, $1 \mu \mathrm{L}$ of Cy2 working solution was added in two sample mixture (each $25 \mu \mathrm{g}$ ) and mixed by vortex. After spinning down, it was wrapped with foil for light cutoff, and then reacted in 30 minutes by being stored into ice. The lete labeling reaction was completed by adding $1 \mu \mathrm{L}$ Lysine solution $(10 \mathrm{mM})$ and it was stored into ice after spinning down. Non-pregnant and pregnant bovine samples were classified as 'Control' and as 'Treated', respectively 
(Table 1). To examine the reproducibility, the experiments were repeated with four gels of non-pregnant and pregnant bovine serum samples.

\section{Separation of proteins by 2-D DIGE}

First dimensional isoelectric focusing: Immobiline DryStrips (pH 3 to 10 nonlinear (NL), $\mathrm{pH} 6$ to 9, and $\mathrm{pH} 4$ to $718 \mathrm{~cm}$; GE Healthcare Bio-Sciences, Sweden) were rehydrated in rehydration buffer (6 M Urea, $2 \mathrm{M}$ thiourea, $4 \%$ 3-[\{3-Cholamidopropyl $\}$ dimethylammonio]-1propanesulfonate [CHAPS]), $0.4 \%$ DTT, $2 \% \quad \mathrm{v} / \mathrm{v}$ immobilized $\mathrm{pH}$ gradient (IPG) buffer $\mathrm{pH} 3$ to $10, \mathrm{pH} 6$ to 11, and $\mathrm{pH} 4$ to 7) overnight. For 2D DIGE experiment, the samples labeled by each CyDye DIGE flour (Cy2, Cy3, and Cy5), $2 \times$ buffer (2 M Thiourea, $7 \mathrm{M}$ Urea, 2\% pH Pharmalayte, $2 \%$ DTT, $4 \%$ CHAPS) was used. The mixed samples were loaded into the anode cup of Multiphor II IEF system (GE Healthcare Bio-Sciences, Sweden), and first dimensional isoelectric focusing was executed. First dimensional isoelectric focusing started from $100 \mathrm{~V}$ and gradually increased to final voltage of $8,000 \mathrm{~V}$, and it was executed during total $1.5 \times 10^{5} \mathrm{Vh}$ by setting the current with maximum value of $75 \mu \mathrm{A}$. To make a preparative picking gel for identification of protein spots, $2 \mathrm{mg}$ of preparative serum protein samples were mixed with rehydration buffer (6 M Urea, $2 \mathrm{M}$ thiourea, 4\% CHAPS, 0.4\% DTT, 2\% v/v IPG buffer $\mathrm{pH} 3$ to $10, \mathrm{pH} 6$ to 11 and $\mathrm{pH} 4$ to 7) to a final volume of $450 \mu \mathrm{L}$.

Second dimensional gel electrophoresis: For DIGE experiment, $8 \%$ to $16 \%$ linear gradient SDS polyacrylamide gel was made using low fluorescent glass plate, and general glass plate was applied for $(200 \times 250 \times 1.0 \mathrm{~mm})$ preparative gel. The equilibrated IPG strips after the first dimension electrophoresis were placed onto SDS polyacrylamide gels. The gels were placed into the Ettan DALT system (GE Healthcare Bio-Sciences, Sweden), then run at $10 \mathrm{~mA}$ per gel until the bromophenol blue marker dye disappeared at the bottom of the gel.

\section{Gel staining}

After the second dimensional separation was executed,

Table 1. The experimental design using CyDye DIGE fluor minimal dyes

\begin{tabular}{lccc}
\hline Gel number & Cy2 & Cy5 & Cy3 \\
\hline 1 & Pooled standard & Control 1 & Treated 1 \\
2 & Pooled standard & Treated 1 & Control 1 \\
3 & Pooled standard & Control 2 & Treated 2 \\
4 & Pooled standard & Treated 2 & Control 2 \\
\hline
\end{tabular}

DIGE, difference gel electrophoresis.

The Controls are non-pregnancy serum samples and Treated samples for pregnant serum of day 21 Holstein dairy cattle after artificial insemination. The pooled standards are mixture of pregnant and nonpregnant serum samples for internal standard. the preparative picking gels were stained with colloidal CBB G-250 for picking of spots. The gels were fixed in fixation solution (40\% methyl alcohol, $5 \%$ phosphoric acid) for $1 \mathrm{~h}$ and stained with colloidal CBB G-250 for $24 \mathrm{~h}$ at room temperature. Then the gel was destained in solution containing $1 \%$ acetic acid until the appropriate background was obtained.

\section{Image analysis}

Image detection of the DIGE gel: After washing lowfluorescence glass plate by distilled water cleanly, then fluorescence image was detected by using Typhoon 9410 Variable Mode Imager (GE Healthcare Bio-Sciences, Sweden) with ImageQuant Software (GE Healthcare BioSciences, Sweden). Cy2 fluorescence image was detected in $488 \mathrm{~nm}$ laser and $520 \mathrm{~nm}$ BP (band pass) 40 emission filter, Cy3 fluorescence image in $532 \mathrm{~nm}$ laser and $580 \mathrm{~nm}$ BP30 emission filter, and Cy5 fluorescence image was detected in $633 \mathrm{~nm}$ laser and $670 \mathrm{~nm}$ BP30 (Alban et al., 2003; Marouga et al., 2005).

Image analysis of the $2 \mathrm{D}$ gels: The gel images acquired from Typhoon 9410 Variable Mode Imager with ImageQuant software were analyzed by applying DeCyder V. 5.0 Software (both from GE Healthcare Bio-Sciences, Sweden). Gel to gel matching of the standard spot maps from each gel was performed using the DeCyder biological variation analysis (BVA) module. This allowed the statistical analysis of protein abundance changes between samples. Paired Student's $t$-test analysis was performed for every matched spot set. The $\mathrm{p}$ values less than 0.05 were considered statistically significant. The CBB stained gels were analyzed by applying ImageScanner II (GE Healthcare Bio-Sciences, Sweden) with ImageMaster 2D platinum software version 5.0 (GE Healthcare Bio-Sciences, Sweden).

\section{Protein identification by MALDI-TOF mass spectrometer}

In-gel digestion: The protein spots were excised from the preparative pick gel, sliced into $1 \mathrm{~mm}$ in thickness, and transferred to reaction tubes containing $200 \mu \mathrm{L}$ washing solution (50\% v/v acetonitrile, $25 \mathrm{mM} \mathrm{NH} 4 \mathrm{HCO} 3, \mathrm{pH} 7.8)$. The gel particles were incubated for $30 \mathrm{~min}$ in washing solution to remove staining dye and dried $30 \mathrm{~min}$ with vacuum centrifuge. The dried gel pieces were rehydrated with $3 \mu \mathrm{L}$ of trypsin solution $(0.0012 \mu \mathrm{g} / \mu \mathrm{L}$ in $25 \mathrm{mM}$ NH4HCO3, $\mathrm{pH} 7.8$ ) and $5 \mu \mathrm{L}$ of $25 \mathrm{mM} \mathrm{NH} 4 \mathrm{HCO} 3$ was added to tubes including the gel particles, and then incubated $37^{\circ} \mathrm{C}$ for overnight. After completion of the digestion, the supernatant was transferred to another new tube. To extract residual peptides, the gel particles were sonicated for $20 \mathrm{~min}$ at $30^{\circ} \mathrm{C}$ in a solution of $50 \%$ acetonitrile/0.5\% trifluoroacetic acid (TFA). Extracted 
peptides were used for MALDI-TOF mass spectrometer (MS) analysis.

MALDI-TOF MS analysis and peptide fingerprinting: Extracted peptides from in-gel digestion were analyzed using Voyager DE-STR MALDI-TOF MS (Applied Biosystems, Foster City, CA, USA) in the delayed extraction-reflector mode and standard conditions (Ndimba et al., 2005). Approximately $1 \mu \mathrm{L}$ of extracted peptide solution from each gel spot piece, together with the same volume of matrix solution $(10 \mathrm{mg} / \mathrm{mL} \quad \alpha$-ciano-4hydroxycinnamic acid, $0.1 \% \mathrm{v} / \mathrm{v}$ TFA, and $50 \% \mathrm{v} / \mathrm{v}$ acetonitrile), were loaded onto a 96-well MALDI sample plate and crystallized. Spectra were automatically calibrated upon acquisition, using an external three-point calibration. Peak assignment was performed manually using DataExplorer software, which is part of the Voyager-DE STR MALDI-TOF-MS software package (PerSeptive Biosystems, Framingham, MA, USA). Spectra were saved as peak table files (*.pkt) to search against non-redundant protein sequence database on the internet (SWISS-PROT, NCBInr (2010/05/01) Data Bank). The peptide mass fingerprint data were applied to ProFound search engines (http://prowl.rockefeller.edu/prowl-cgi/profound.exe). Search parameters were other mammalia as taxonomy, trypsin as an enzyme, carbamidomethylation of cystein as fixed modification and methionine oxidation as variable modification, and one missed cleavage site with a mass tolerance of less then $500 \mathrm{ppm}$. The protein identification was further validated by ProFound score, sequence coverage and number of peptides matched.

\section{RESULTS AND DISCUSSIONS}

The protein profiles of bovine serum on 2D DIGE gels

In order to compare protein expression patterns of pregnant (21 days) and non-pregnant bovine serums, the serum samples were labeled with fluorescence CyDye DIGE flour (Cy2, Cy3, and Cy5). After executing isoelectric focusing (IEF) using $\mathrm{pH} 3$ to $10 \mathrm{NL}, \mathrm{pH} 6$ to 9 and $\mathrm{pH} 4$ to 7 IPG strip gels by mixing three samples labeled with fluorescence CyDye DIGE flour, they were separated in $8 \%$ to $16 \%$ polyacrylamide gradient gel for SDS-PAGE. Three images per gel were visualized by Typhoon, a fluorescence image analyzer, and ImageQuant software. The protein patterns were detected to colors of blue (Cy2, Internal standard), green (Cy3, pregnancy), and red (Cy5, non-pregnancy) by fluorescence CyDye DIGE flour. Expression pattern of proteins were observed by comparing protein spots which were expressed in serum of pregnant bovine and non-pregnancy bovine by using DeCyder Software V5.0 (GE Healthcare Bio-Sciences, Sweden) for three image gels from one gel (Figure 1A, B, C, and D).

Approximately 1,500 spots were detected by DeCyder differential in gel analysis module in 2D gel of pH 3 to 10 . Minimal filtering was performed to eliminate dust particles

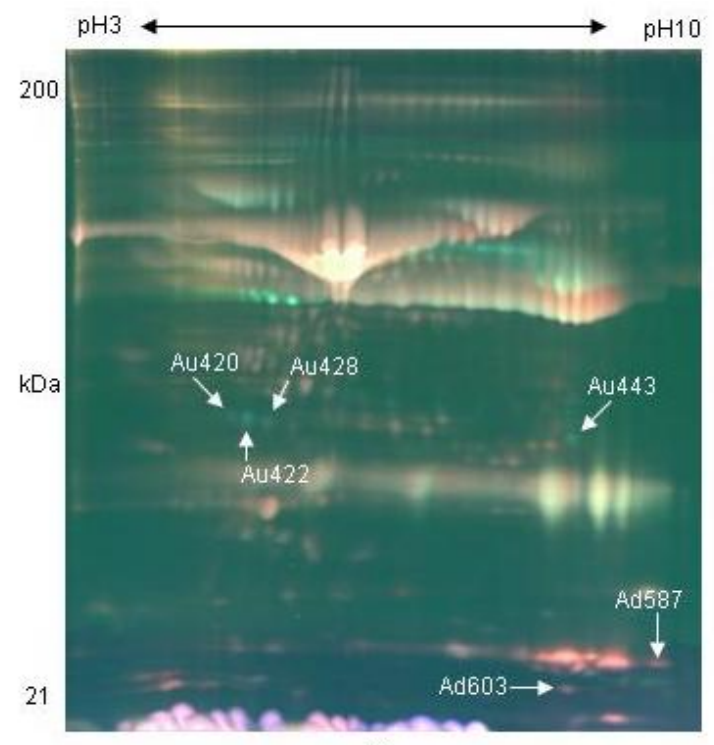

A)
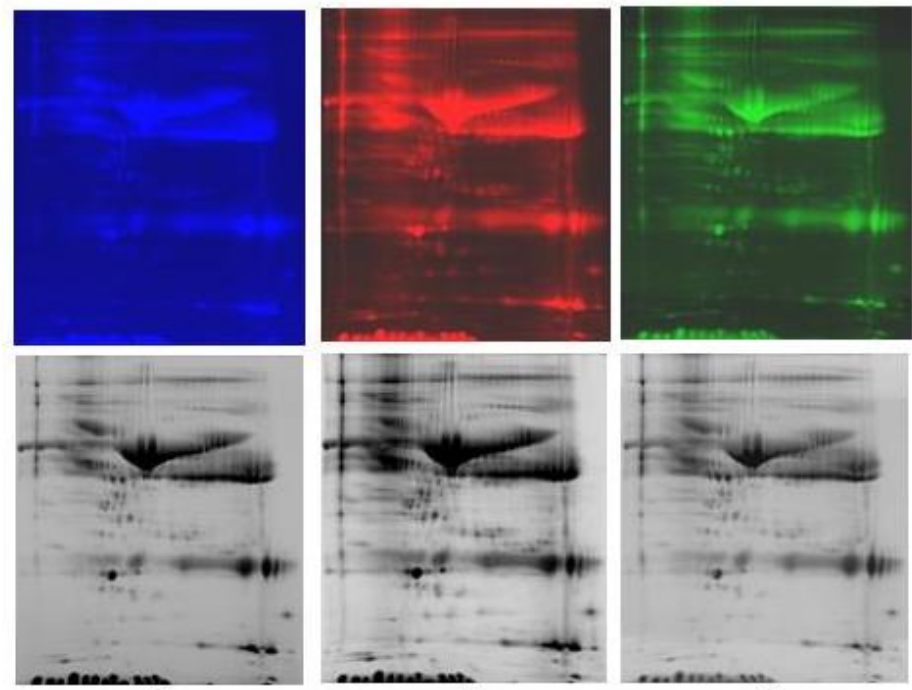

B)

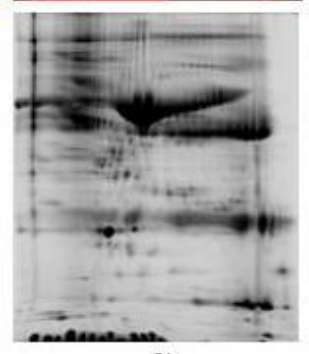

C)

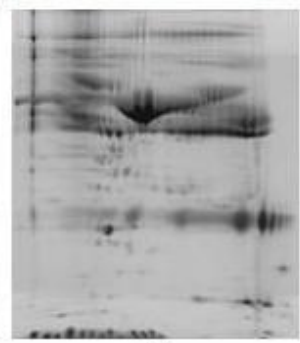

D)

Figure 1. Two dimensional-fluorescence difference gel electrophoresis (DIGE) gel of bovine serum proteins labeled with CyDyes. The protein extracted from the bovine serum of pregnant and non-pregnant as visualized by CyDye DIGE flour. First dimension was pH 3 to 10 NL IPG gel and second dimension was a range of 10 to $200 \mathrm{kDa}$ in an $8 \%$ to $16 \%$ gradient gel. Comparison of proteomes of serum sample of pregnant and non-pregnancy Holstein dairy cattle day 21 after artificial insemination (A: Image overlay, B: mixture of pregnant and non-pregnancy bovine serum labeled with $\mathrm{Cy} 2$ for internal standard, C: non-pregnant serum labeled with Cy5 for Control, D: 21 days pregnant serum labeled with Cy3). NL, nonlinear. (Upper: fluorescence color images, lower: black and white-transformed images). 
etc, whilst avoiding the exclusion of potentially valuable protein spots. Gel to gel matching of the standard spot maps from each gel was performed using the DeCyder BVA module. After BVA analysis, about 600 spots were detected in $2 \mathrm{D}$ gel of $\mathrm{pH} 3$ to 10 , and they were mainly observed in molecular weight of 20 to $50 \mathrm{kDa}$ (Figure 1A). A total of 6 spots were differentially distributed with at least 1.5 -fold changes in volume between the non-pregnant and pregnant serum (Figure 2). Analysis of the 2D gels revealed the presence of about 630 spots in $\mathrm{pH} 6$ to $92 \mathrm{D}$ gel (Figure 3A) and 770 spots in $\mathrm{pH} 4$ to 7 2D gels (Figure 4A). And 6 and
2 protein spots were detected to be differentially expressed in $\mathrm{pH} 6$ to 9 and pH 4 to 7 2D gels, respectively (Figure 3B and Figure 4B). These protein spots were visualized on the CBB stained preparative gels and selected for identification analysis.

\section{Protein identification}

The protein of interest (up- or down-regulated) was defined from the $\mathrm{Cy} 3$ or $\mathrm{Cy} 5$ images, and its corresponding spot in CBB stained preparative picking gel images were matched. The protein spots were excised manually and

\section{Up regulated}
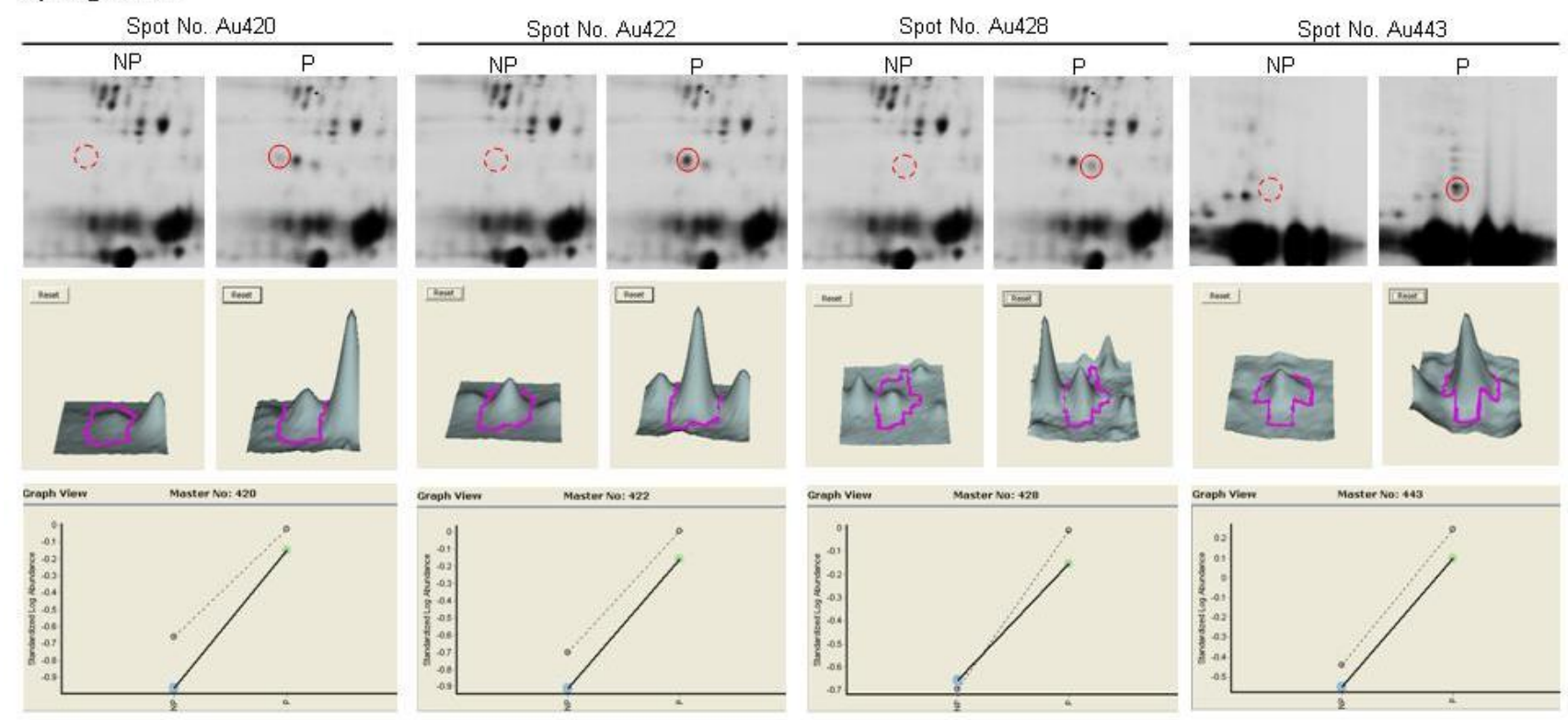

\section{Down regulated}
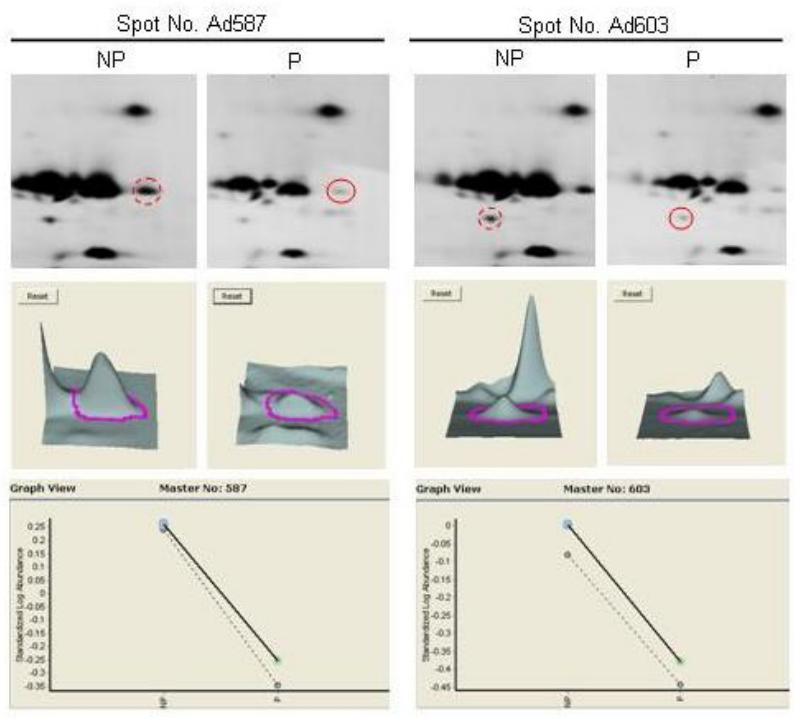

Figure 2. Differentially expressed protein spots of $\mathrm{pH} 3-10 \mathrm{NL}$. The spot pairs of up-regulated and down-regulated proteins in bovine serum were shown, with the DeCyder matched spots (NP, non-pregnancy bovine serum, $\mathrm{P}$, pregnancy bovine serum). 3D representation of spot volumes derived from differentially expressed proteins. Graphical representations of all matched spots for particular protein are shown in the lower panels (dotted and solid lines were plotted with two independent values from the two sets of gels in which pregnant and normal samples ran). 

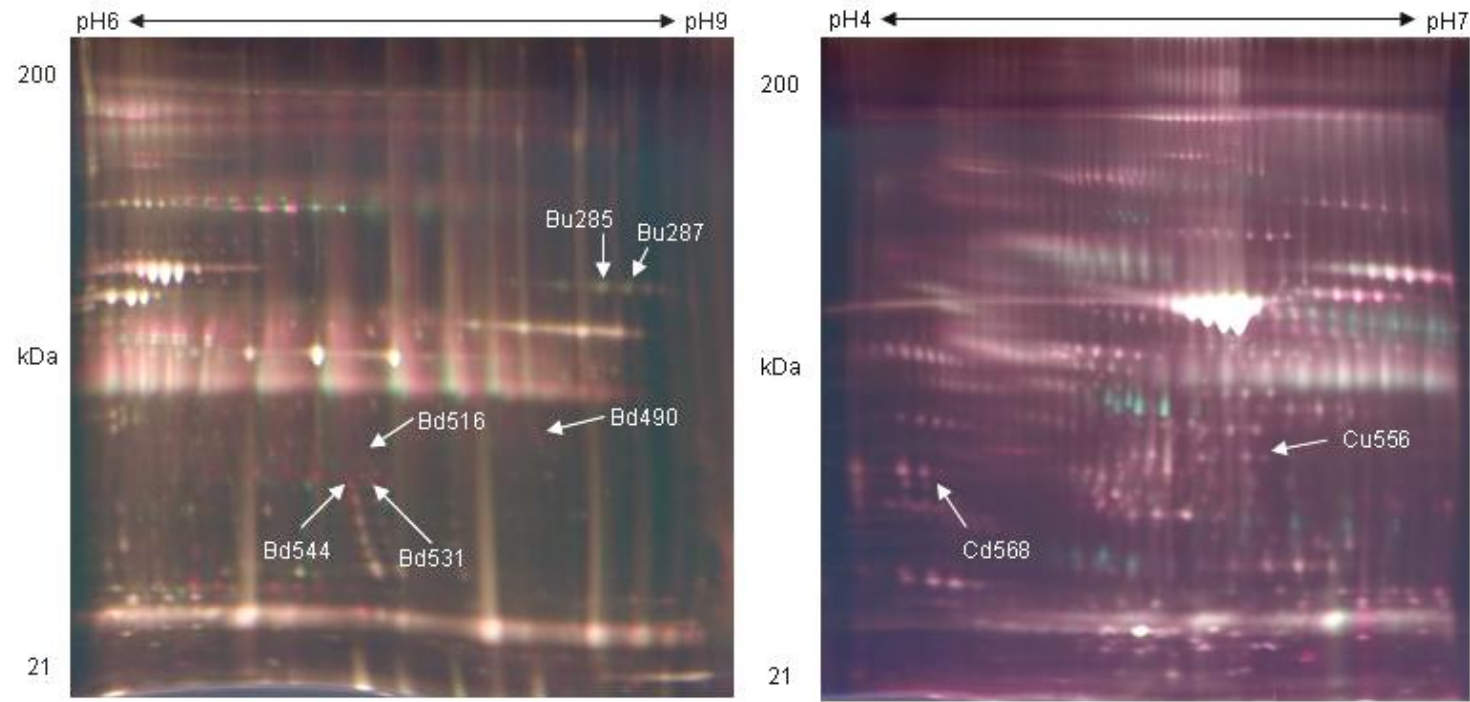

Figure 3. 2D difference gel electrophoresis gel image and differentially expressed protein spots of pH 6 to 9 . The spot pairs of upregulated and down-regulated proteins in bovine serum were shown, with the DeCyder matched spots (NP, non-pregnancy bovine serum; $\mathrm{P}$, pregnancy bovine serum). 3D representation of spot volumes derived from differentially expressed proteins.

A)
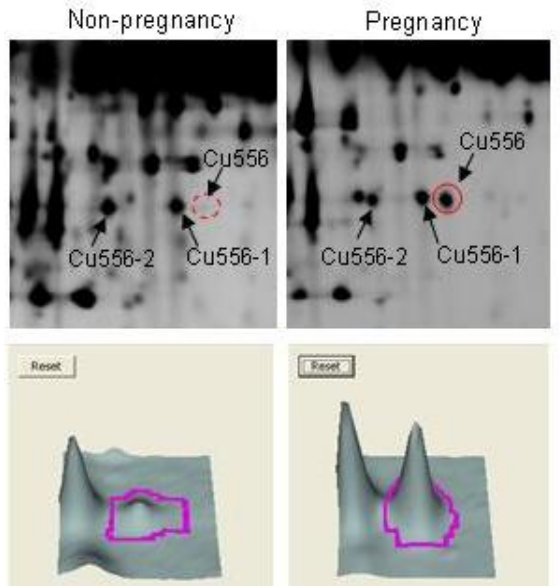

Graph View

Master No: $\mathbf{5 5 6}$

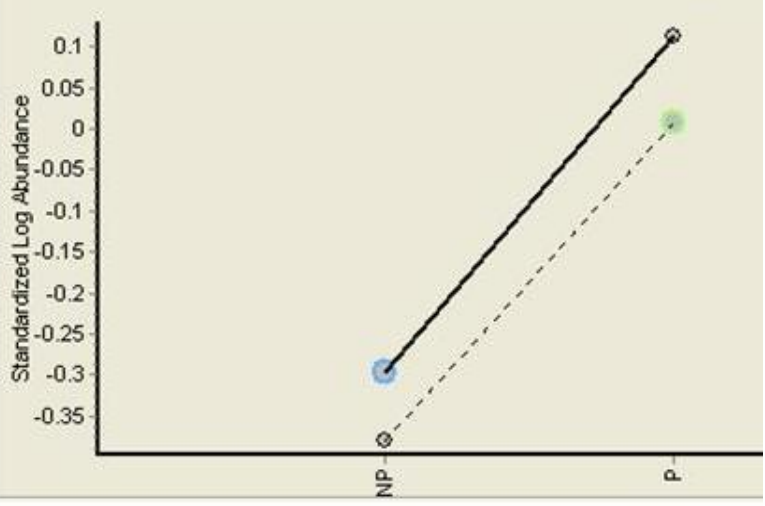

B)

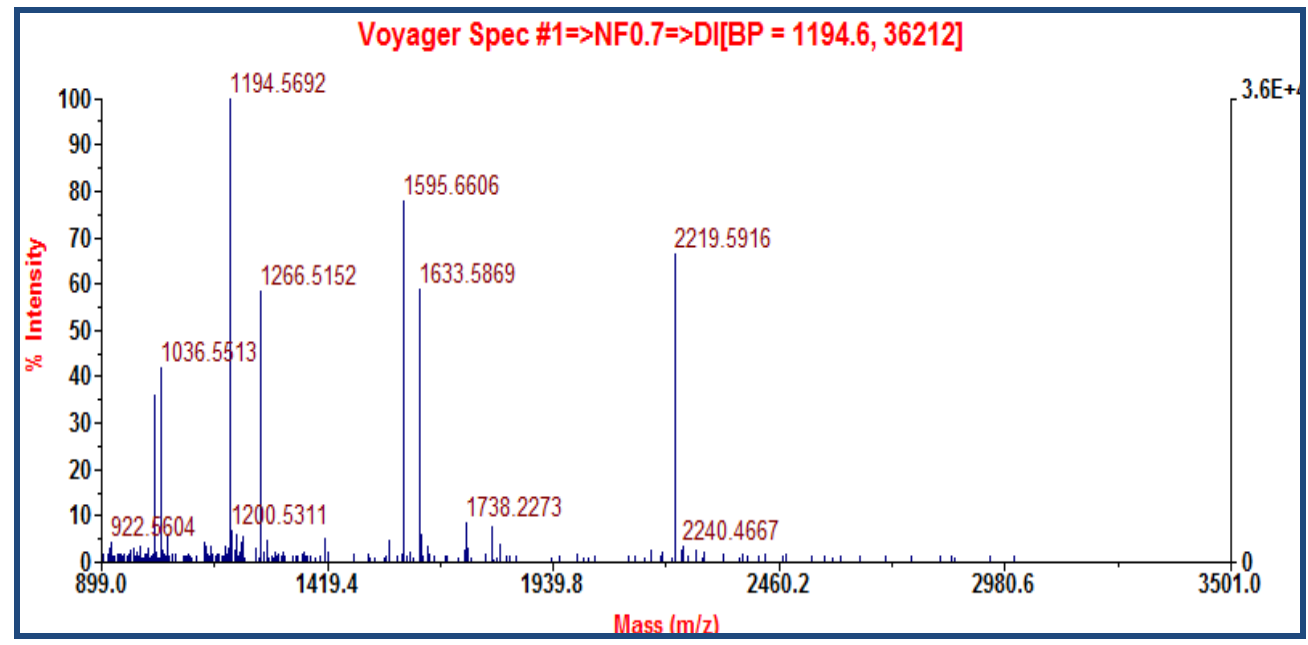

Figure 4. Peptide mass fingerprint of spot Cu556. A) The specific up-regulated spots was expressed on 2D polyacrylamide gel electrophorysis gels in bovine pregnancy serum. B) MALDI-TOF mass spectrometer spectrum of spots. 
Table 2. Identification of protein interest in bovine serum

\begin{tabular}{|c|c|c|c|c|c|c|c|c|}
\hline Spot ID & Est'd $Z^{1}$ & Accession No. & Protein information & $\begin{array}{c}\text { Sequence } \\
\text { coverage } \\
(\%)\end{array}$ & $\mathrm{pI}$ & $\mathrm{pI}(\mathrm{ex})$ & $\mathrm{kDa}$ & $\mathrm{kDa}(\mathrm{ex})$ \\
\hline \multicolumn{9}{|c|}{ Up-regulation } \\
\hline AU402 & 2.29 & AAB37381.2 & IgG1 heavy chain constant region (Bos taurus) & 40 & 6.1 & 4.8 & 36.68 & 45.5 \\
\hline AU422 & 2.26 & AAB37381.2 & IgG1 heavy chain constant region (Bos taurus) & 33 & 6.1 & 4.9 & 36.68 & 45.4 \\
\hline AU428 & 2.12 & AAB37381.2 & IgG1 heavy chain constant region (Bos taurus) & 26 & 6.1 & 5.0 & 36.68 & 45.3 \\
\hline AU443 & 2.19 & $1 \mathrm{DEQ} \mid \mathrm{A}$ & $\begin{array}{l}\text { Chain A, the crystal structure of modified } \\
\text { bovine fibrinogen (At } \sim 4 \text { angstrom resolution) }\end{array}$ & 38 & 8.6 & 8.8 & 43.12 & 39.0 \\
\hline CU556 & 2.32 & P23805 & CONG_BOVIN conglutinin precursor & 34 & 5.8 & 6.1 & 38.47 & 50.5 \\
\hline CU556-1 & 2.33 & $\mathrm{P} 23805$ & CONG_BOVIN conglutinin precursor & 36 & 5.8 & 6.0 & 38.47 & 50.5 \\
\hline CU556-2 & 2.31 & P23805 & CONG_BOVIN conglutinin precursor & 32 & 5.8 & 5.8 & 38.47 & 50.5 \\
\hline $\mathrm{Bu} 285$ & & & No identified & & & & & \\
\hline $\mathrm{Bu} 287$ & & & No identified & & & & & \\
\hline \multicolumn{9}{|c|}{ Down-regulation } \\
\hline AD587 & 1.82 & $1 \mathrm{HDA} \mid \mathrm{A}$ & Chain A, Hemoglobin (Deoxy) & 44 & 9.5 & 15.04 & 15.04 & 24.3 \\
\hline AD603 & 1.81 & AAC99786.1 & Complement component 3 (Bos taurus) & 36 & 8.8 & 17.41 & 17.41 & 22.1 \\
\hline BD490 & 1.83 & $1 \mathrm{DEQ} \mid \mathrm{A}$ & $\begin{array}{l}\text { Chain A, the crystal structure of modified } \\
\text { bovine fibrinogen (At } \sim 4 \text { angstrom resolution) }\end{array}$ & 32 & 8.0 & 43.12 & 43.12 & 50.1 \\
\hline BD516 & 2.27 & $1 \mathrm{DEQ} \mid \mathrm{A}$ & $\begin{array}{l}\text { Chain A, the crystal structure of modified } \\
\text { bovine fibrinogen (At } \sim 4 \text { angstrom resolution) }\end{array}$ & 30 & 7.2 & 43.12 & 43.12 & 45.9 \\
\hline BD531 & 2.38 & AAB37380.1 & IgG2a heavy chain constant region (Bos taurus) & 24 & 7.2 & 36.55 & 36.55 & 38.6 \\
\hline BD544 & 2.28 & $1 \mathrm{DEQ} \mid \mathrm{A}$ & $\begin{array}{l}\text { Chain A, the crystal structure of modified } \\
\text { bovine fibrinogen (At } \sim 4 \text { angstrom resolution) }\end{array}$ & 34 & 7.1 & 43.12 & 43.12 & 37.7 \\
\hline Cd568 & & & No identified & & & & & \\
\hline
\end{tabular}

subjected to in-gel digestion and analyzed with MALDITOF MS. Raw spectra of samples were processed by DataExplorer software to remove and reduce noises and finally result in a list of monoisotopic peaks. The tryptic peptide masses were used to search for protein candidates in web-based searching software, ProFound (http://129.85.19. 192/profound_bin /Web ProFound.exe).

The 13 spots were identified as the known proteins in SWISS-PROT and NCBInr databases. The search results were evaluated on the basis of accepted standard that take account into the number of peptides matched to the candidate protein and the difference in the number of matched peptides between the candidate proteins and the next best fit, the coverage of candidate protein sequences by the matching peptides of the experimental and theoretical $\mathrm{pI}$ and $M r$ with values (Jensen et al., 1999). The results of the MALDI-TOF MS analysis for the identified spots were listed in Table 2. The identified proteins were conglutinin precursor, bovine fibrinogen, IgG1 heavy chain constant region, hemoglobin, complement component 3 and IgG2a heavy chain constant region. Five proteins were identified in up-regulation such as bovine fibrinogen, conglutinin precursor and IgG1 heavy chain constant region. The downregulated proteins were hemoglobin, complement component 3 , bovine fibrinogen and $\operatorname{IgG} 2 \mathrm{a}$ heavy chain constant region. The conglutinin precursor protein (spot no.Cu556), which was specific expressed in pregnancy serum of the $\mathrm{pH} 4$ to 7 gel (Figure $4 \mathrm{~A}, \mathrm{~B}$ ). However, we found that the spot Cu556-1 and Cu556-2 were the same conglutinin precursor protein, even though the sequence coverage percent values revealed with $34 \%, 36 \%$, and $32 \%$ difference (Table 2). Conglutinin is known to be a collectin family member protein and a part of the innate immune system (Holmskov et. al., 2003). Its function is to bind to the surface oligosaccharide of microorganisms and eliminate microorganisms by complement activation, activation of phagocytes or inhibit microbial growth. It is considered that more research should be executed further for identifying conglutinin protein function related with pregnancy and sequences of three different spots related with bovine pregnancy.

\section{ACKNOWLEDGMENTS}

This work was supported by the BioGreen 21 Program of the Rural Development Administration (grant no. PJ01119601) and the Bio-industry Technology Development Program (grant no. IPET312060-5) of the Ministry for Agriculture, Food and Rural Affairs, Republic of Korea. 


\section{REFERENCES}

Anderson, N. G., A. Matheson, and N. L. Anderson. 2001. Back to the future: the human protein index (HPI) and the agenda for post-proteomic biology. Proteomics 1:3-12.

Alban, A., S. O. David, L. Bjorkesten, C. Andersson, E. Sloge, S. Lewis, and I. Currie. 2003. A novel experimental design for comparative two-dimensional gel analysis: Two-dimensional difference gel electrophoresis incorporating a pooled internal standard. Proteomics 3:36-44

Bartol, F. F., R. M. Roberts, F. W. Bazer, and W. W. Thatcher. 1985. Characterization of proteins produced in vitro by bovine endometrial explants. Biol. Reprod. 33:745-759.

Berendt, F. J., T. Fröhlich, S. E. Schmidt, H. D. Reichenbach, E. Wolf, and G. J. Arnold. 2005. Holistic differential analysis of embryo-induced alterations in the proteome of bovine endometrium in the preattachment period. Proteomics 5:25512560.

Bichsel, V. E., L. A. Liotta, and E. F. Petricoin III. 2001. Cancer proteomics: from biomarker discovery to signal pathway profiling. Cancer J. 7:69-78

Butler, J. E., W. C. Hamilton, R. G. Sasser, C. A. Ruder, G. M. Hass, and R. J. Williams. 1982. Detection and partial characterization of two bovine pregnancy-specific proteins. Biol. Reprod. 26:925-933.

Chromy, B. A., A. D. Gonzales, J. Perkins, M. W. Choi, M. H. Corzett, B. C. Chang, C. H. Corzett, and S. L. McCutchenMaloney. 2004. Proteomic analysis of human serum by twodimensional differential gel electrophoresis after depletion of high-abundant proteins. J. Proteome Res. 3:1120-1127.

Gharbi, S., P. Gaffney, A. Yang, M. J. Zvelebil, R. Cramer, M. D. Waterfield, and J. F. Timms. 2002. Evaluation of twodimensional differential gel electrophoresis for proteomic expression analysis of a model breast cancer cell system. Mol Cell. Proteomics 1:91-98.

Gorg, A., C. Obermaier, G. Boguth, A. Harder, B. Scheibe, R. Wildgruber, and W. Weiss. 2000. The current state of twodimensional electrophoresis with immobilized $\mathrm{pH}$ gradients. Electrophoresis 21:1037-1053.

Hochstrasser, D. F., S. Frutiger, M. R. Wilkins, G. Hughes, and J. C. Sanchez. 1997. Elevation of apolipoprotein E in the CSF of cattle affected by BSE. FEBS Lett. 416:161-163.

Holmskov, U., S. Thiel, and J. C. Jensenius. 2003. Collections and ficolins: humoral lectins of the innate immune defense. Ann. Rev. Immunol. 21:547-578.

Knickerboker, J. J., W. W. Thatcher, F. W. Bazer, M. Drost, D. H. Barron, K. B. Fincher, and R. M. Roberts. 1986. Proteins secreted by day-16 to -18 bovine conceptuses extend corpus luteum function in cows. J. Reprod. Fertil. 77:381-391.

Manabe, T., Y. Takahashi, and T. Okuyama. 1987. Identification of bovine fetal and adult serum/plasma proteins by twodimensional electrophoresis and immunochemical staining. Electrophoresis 8:573-579.

Marouga, R., S. David, and E. Hawkins. 2005. The development of the DIGE system: 2D fluorescence difference gel analysis technology. Anal. Bioanal. Chem. 382:669-678.

Morita, A., E. Miyagi, H. Yasumitsu, H. Kawasaki, H. Hirano, and F. Hirahara. 2006. Proteomic search for potential diagnostic markers and therapeutic targets for ovarian clear cell adenocarcinoma. Proteomics 6:5880-5890.
Nation, D. P., J. Malmo, G, M. Davis, and K. L. Macmillan. 2003. Accuracy of bovine pregnancy detection using transrectal ultrasonography at 28 to 35 days after insemination. Aust. Vet. J. 81:63-65.

Ndimba, B. K., S. Chivasa, W. J. Simon, and A. R. Slabas. 2005. Identification of Arabidopsis salt and osmotic stress responsive proteins using two-dimensional difference gel electrophoresis and mass spectrometry. Proteomics 5:4185-4196.

Oltenacu, P. A., J. D. Ferguson, and A. J. Lednor. 1990. Economic evaluation of pregnancy diagnosis in dairy cattle: A decision analysis approach. J. Dairy Sci. 73:2826-2831.

Perenyi, Z. S., O. Szenci, J. Sulon, P. V. Drion, and J. F. Beckers. 2002. Comparison of the ability of three radioimmunoassay to detect pregnancy-associated glycoproteins in bovine plasma. Reprod. Domest. Anim. 37:100-104.

Pyo, J., S. I. Hwang, J. Oh, S. J. Lee, S. C. Kang, J. S. Kim, and J. Lim. 2003. Characterization of a bovine pregnancy-associated protein using two-dimensional gel electrophoresis, N-terminal sequencing and mass spectrometry. Proteomics 3:2420-2427.

Raggiaschi, R., C. Lorenzetto, E. Diodato, A. Caricasole, S. Gotta, and G. C. Terstappen. 2006. Detection of phosphorylation patterns in rat cortical neurons by combining phosphatase treatment and DIGE technology. Proteomics 6:748-756.

Sasser, R. G., C. A. Ruder, K. A. Ivani, J. E. Butler, and W. C. Hamilton. 1986. Detection of pregnancy by radioimmunoassay of a novel pregnancy-specific protein in serum of cows and a profile of serum concentrations during gestation. Biol. Reprod. 35: 936-942.

Sasser, R. G., J. Crock, and C. A. Ruder-Montgomery. 1989. Characteristics of pregnancy-specific protein B in cattle. J. Reprod. Fertil. Suppl. 37:109-113.

Talamo, F., C. D’Ambrosio, S. Arena, P. D. Vecchio, L. Ledda, G. Zehender, L. Ferrara, and A. Scaloni. 2003. Proteins from bovine tissues and biological fluids: Defining a reference electrophoresis map for liver, kidney, muscle, plasma and red blood cells. Proteomics 3:440-460.

Tong, R., J. Shaw, B. Middleton, R. Rowlinson, S. Rayner, J. Young, F. Pognan, E. Hawkins, I. Currie, and M. Davision. 2001. Validation and development of fluorescence twodimensional differential gel electrophoresis proteomics technology. Proteomics 1:377-396.

Unlu, M., M. E. Morgan, and J. S. Minden. 1997. Difference gel electrophoresis. A single gel method for detecting changes in protein extracts. Electrophoresis 18:2071-2077.

Yan, J. X., A. T. Devenish, R. Wait, T. Stone, S. Lewis, and S. Fowler. 2002. Fluorescence two-dimensional difference gel electrophoresis and mass spectrometry based proteomic analysis of Escherichia coli. Proteomics 2:1682-1698.

Yuan, C., Y. Guo, R. Ravi, K. Przyklenk, N. Shilkofsk, R. Diez, R. N. Cole, and A. M. Murphy. 2006. Myosin binding protein C is differentially phosphorylated upon myocardial stunning in canine and rat hearts-evidence for novel phosphorylation sites. Proteomics 6:4176-4186.

Zhou, G., H. Li, D. DeCamp, S. Chen, H. Shu, Y. Gong, M. Flaig, J. W. Gillespie, N. Hu, P. R. Taylor, M. R. Emmert-Buck, L. A. Liotta, E. F. 3rd. Petricoin, and Y. Zhao. 2002. 2D differential In-gel electrophoresis for the identification of Esophageal Scans Cell cancer-specific protein markers. Mol. Cell. Proteomics 1:117-123. 